Supplement of Hydrol. Earth Syst. Sci., 23, 1885-1904, 2019

https://doi.org/10.5194/hess-23-1885-2019-supplement

(c) Author(s) 2019. This work is distributed under

the Creative Commons Attribution 4.0 License.

(c) (1)
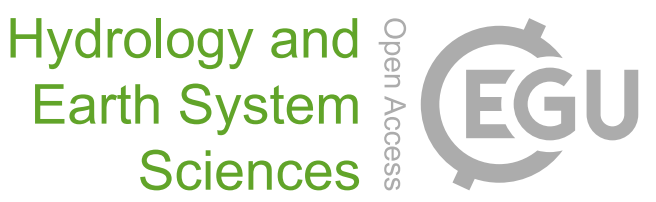

Supplement of

\title{
Anthropogenic and catchment characteristic signatures in the water quality of Swiss rivers: a quantitative assessment
}

Martina Botter et al.

Correspondence to: Martina Botter (botter@ifu.baug.ethz.ch)

The copyright of individual parts of the supplement might differ from the CC BY 4.0 License. 


\section{S1. The impact of detection thresholds on the results}

The NADUF data are collected following the ISO/EN methods for water analysis. Uncertainties in the data may rise due to the detection limits of the instruments or analysis methods. The specifics of the data collection methods including also the detection limits are reported at the following link: https://www.bafu.admin.ch/dam/bafu/en/dokumente/hydrologie/fachinfo-daten/naduf-methoden-chemischeanalysen-eawag-2018.pdf.download.pdf/Methoden_NADUF_2018 E.pdf. The differences in concentration magnitude across catchments are higher than the sensitivity of the instruments and therefore are significant.

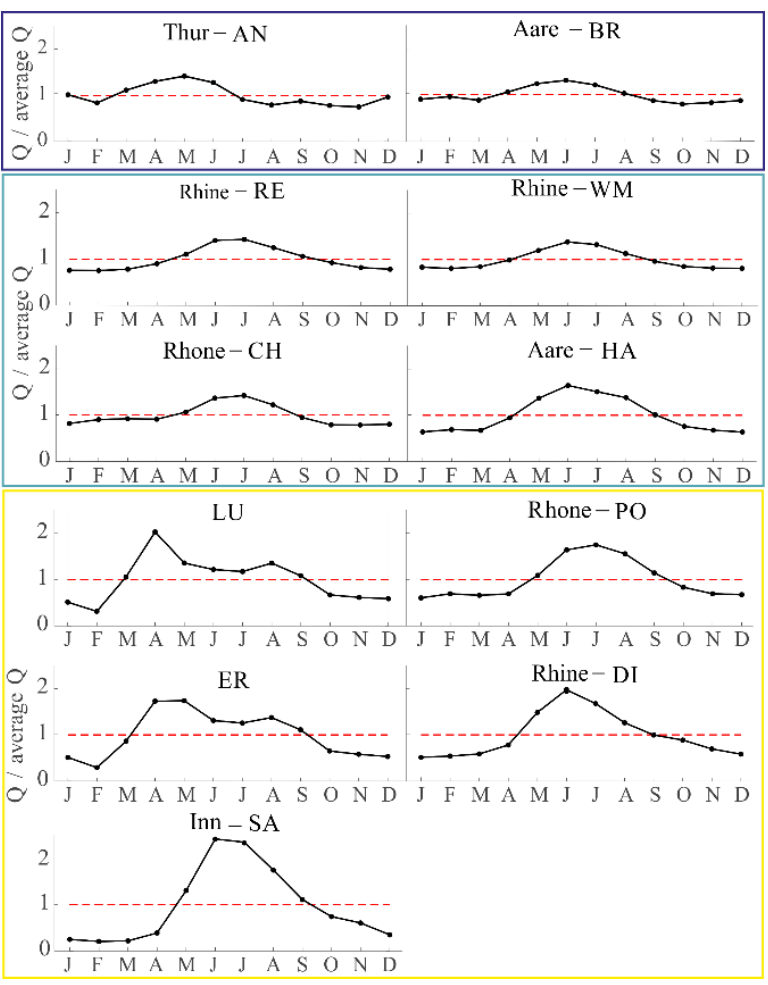

Figure S1: Discharge seasonality. Each point represents the monthly average discharge normalized by the average discharge over the monitoring period, while the red dashed line is the average normalized discharge over the entire monitoring period. Blue upper box: Swiss Plateau catchments. Light blue middle box: hybrid catchments. Yellow bottom box: Alpine catchments. The hydrological regimes are clustered according to the main categories reported by Weingartner and Aschwanden, 1992. 


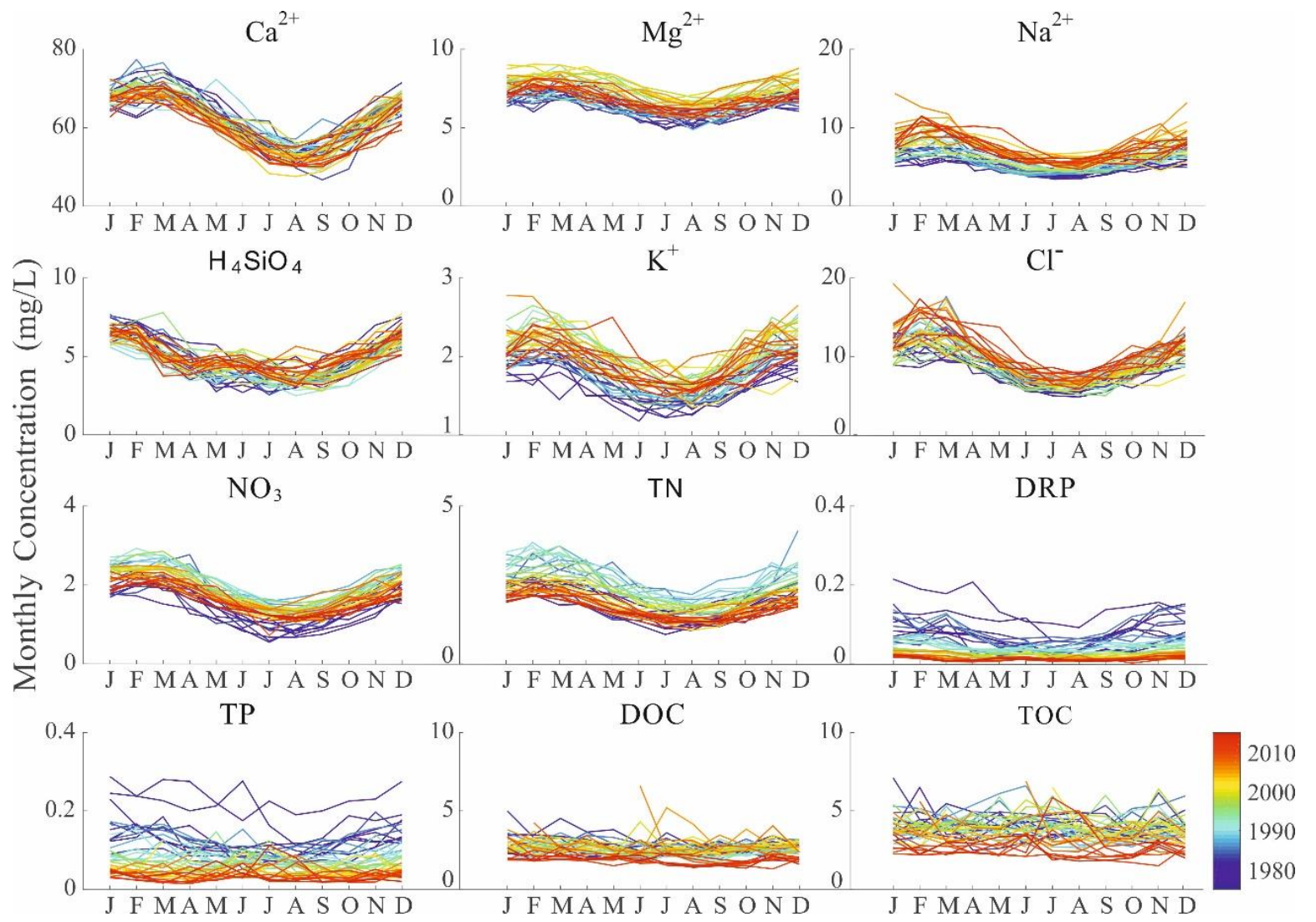

Figure S2: Long-term solutes trends. Each line represents the monthly average concentration of each solute. The color bar indicates the years of the monitoring period, from the first year (blue) to the last year (red). The presented figure refers to the Rhine catchment at the monitoring section of Rekingen. 

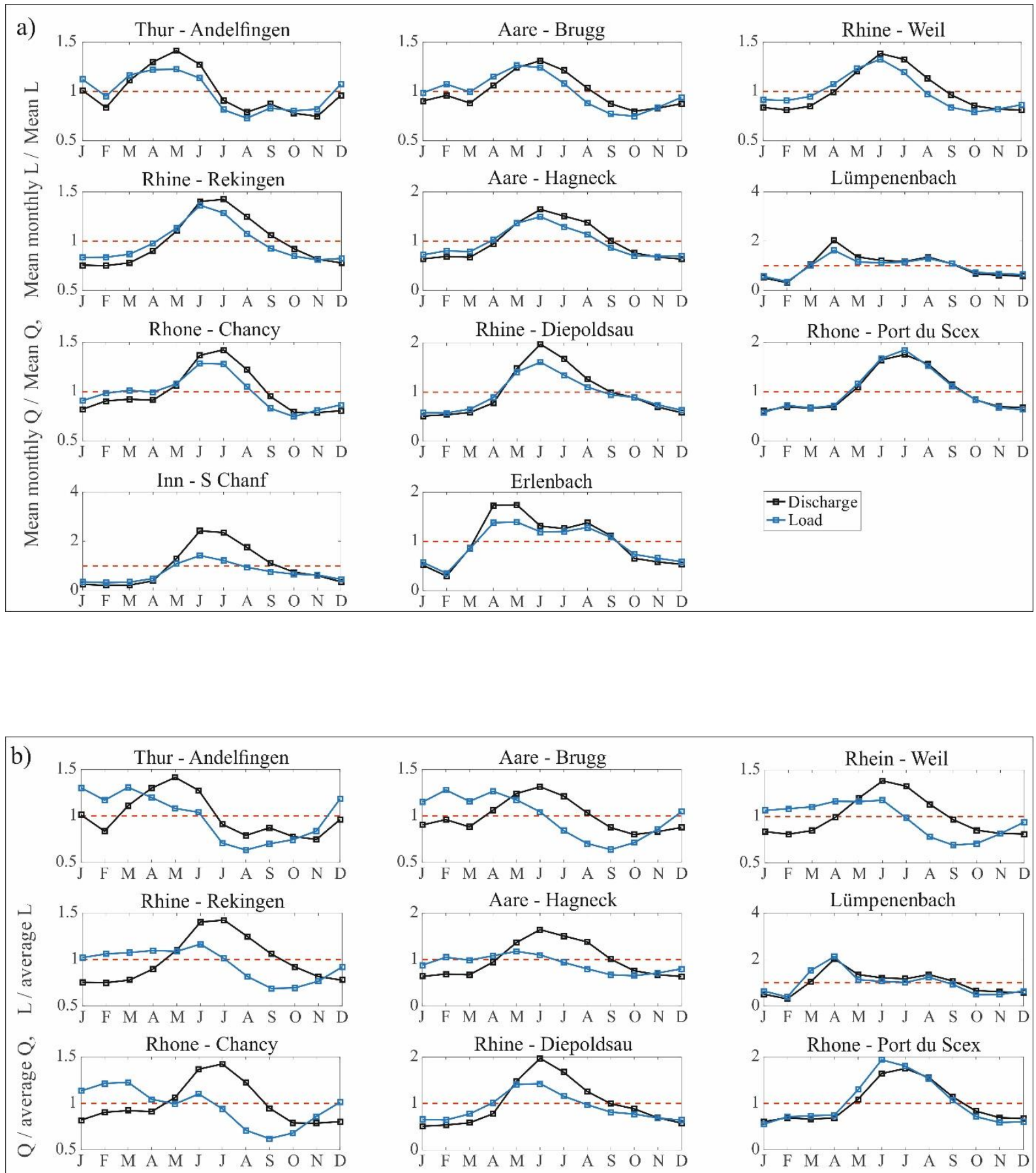

Rhone - Port du Scex
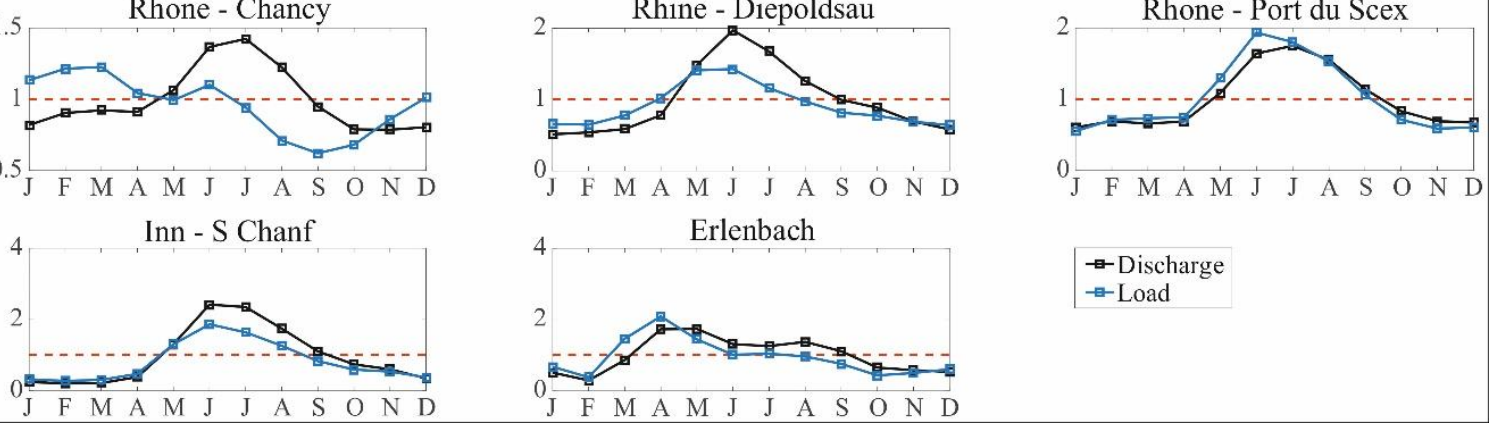

$$
\begin{aligned}
& \text { - Discharge } \\
& \text { - Load }
\end{aligned}
$$

Figure S3. Monthly average of discharge (black) and solute load (blue) normalized by the average of the entire monitoring period. The red horizontal line represents the reference value 1 (i.e., mean). The subpanel (a) refers to Calcium and subpanel (b) to Nitrate. Calcium is originated by rock weathering and it mostly follows the seasonality of discharge. Nitrate, instead, is strongly related to the anthropic activities and in the most impacted catchments (i.e. Thur, Aare - Brugg) the load has a seasonality, which is different from the seasonality of discharge. 


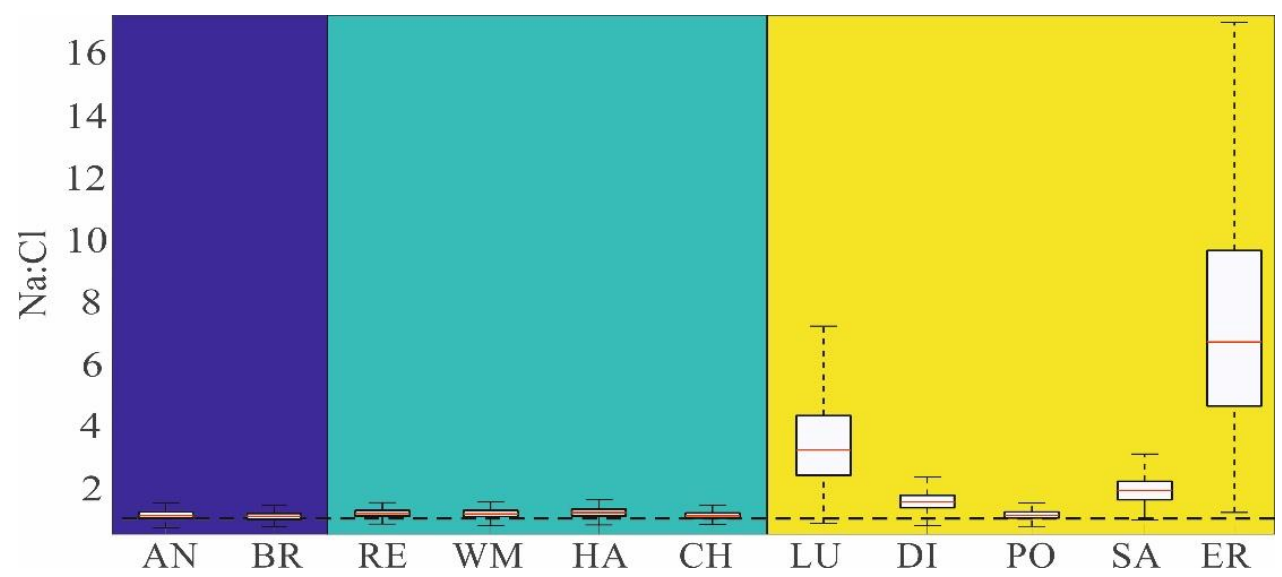

Figure S4. Molar Na:Cl ratio across catchments. Catchments with higher inhabitant density (AN, BR, RE, WM, $\mathrm{HA}, \mathrm{CH}$ ) show molar ratio between $\mathrm{Na}^{+}$and $\mathrm{Cl}^{-}$close to 1 , while catchments with lower human presence (PO, DI, SA) show higher values. Lümpenenbach and Erlenbach catchments show very high molar $\mathrm{Na:Cl} \mathrm{ratio,} \mathrm{as} \mathrm{the}$ number of their inhabitants is 0 and deicing salt is not used.

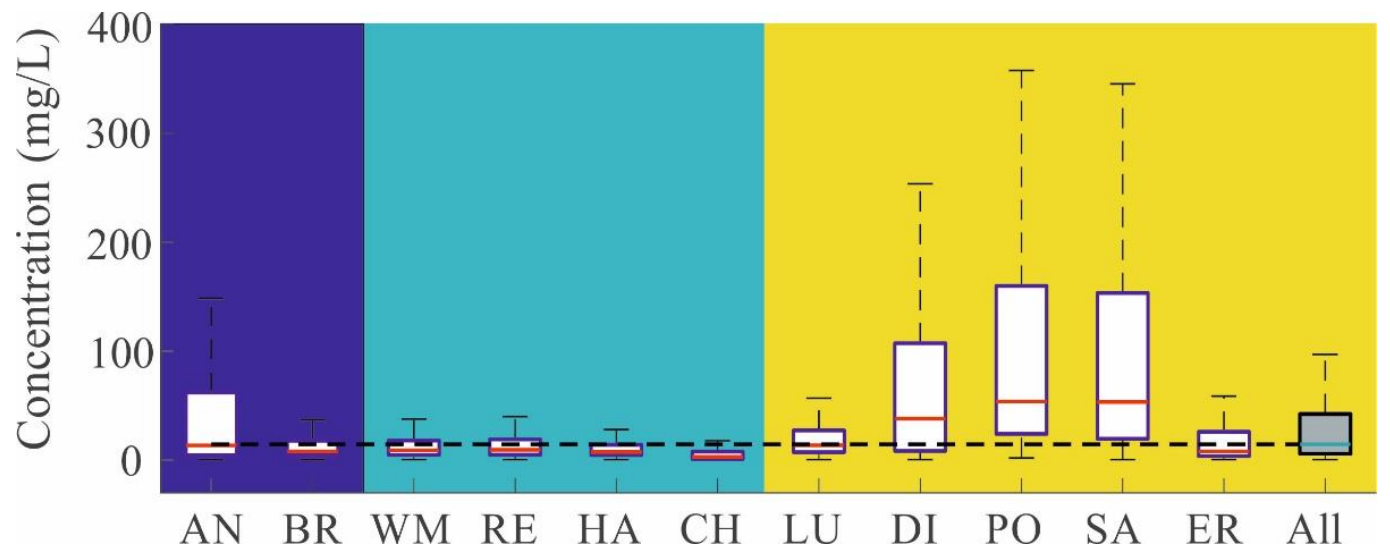

Figure S5. Suspended solids concentrations across the catchments. The boxplot shows the suspended solid concentrations across the eleven catchments, ordered from the Swiss Plateau (blue background), to the hybrid (light blue background) and Alpine (yellow background) catchments. The Alpine catchments show much higher concentrations and variability. 

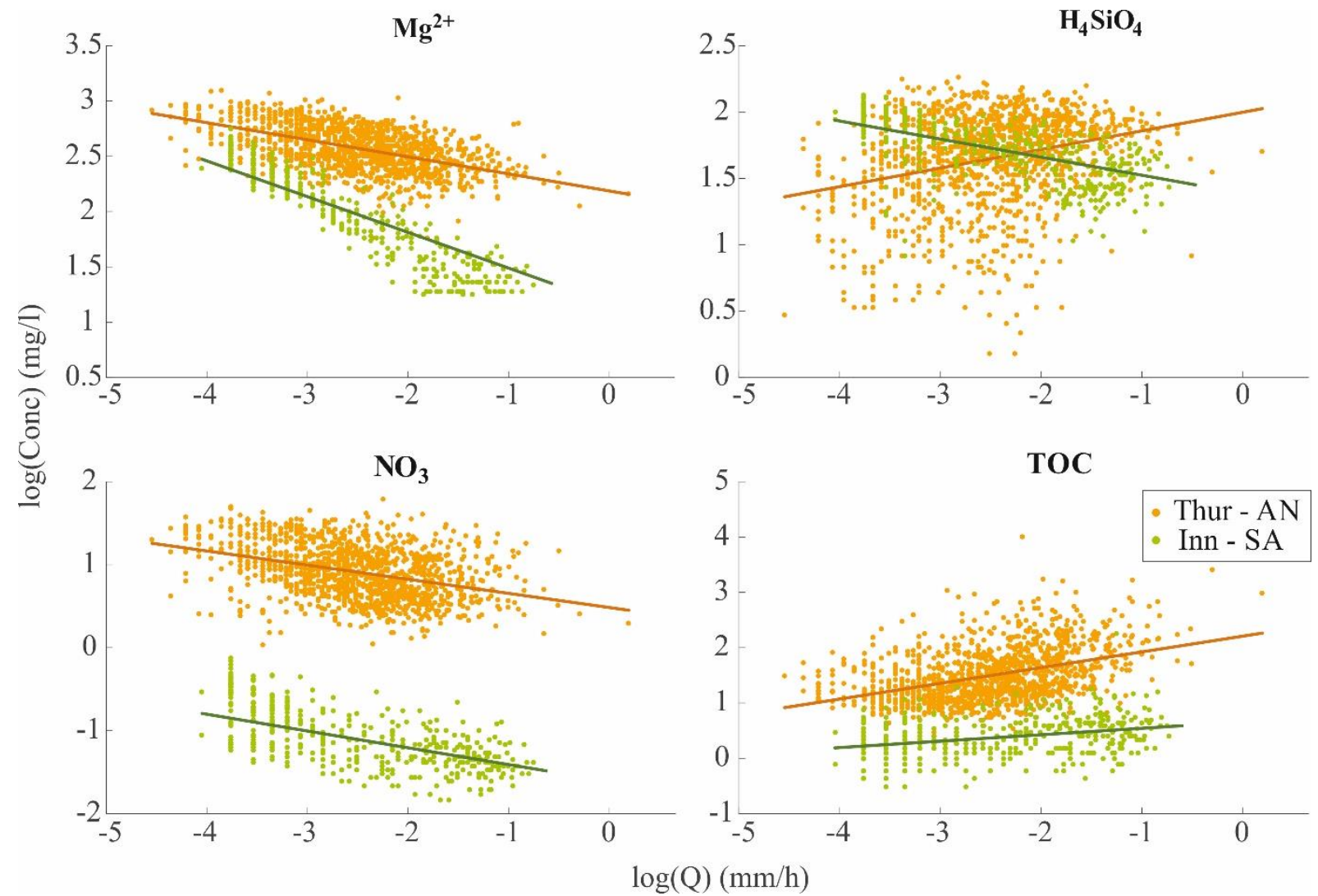

81

Figure S6. Examples of C-Q relations. The patterns of the linear C-Q relation of some solutes $\left(\mathrm{Mg}^{2+}, \mathrm{H}^{4} \mathrm{SiO}^{4}\right.$, $\mathrm{NO}^{3}$ and TOC) are plotted in a log-log space. Orange points and line refer to the Swiss Plateau catchment Thur (AN), while green ones refer to the Alpine catchment Inn (SA). The variability of concentrations for all the solutes across all the catchments is a few orders of magnitude less than the variability of discharge.
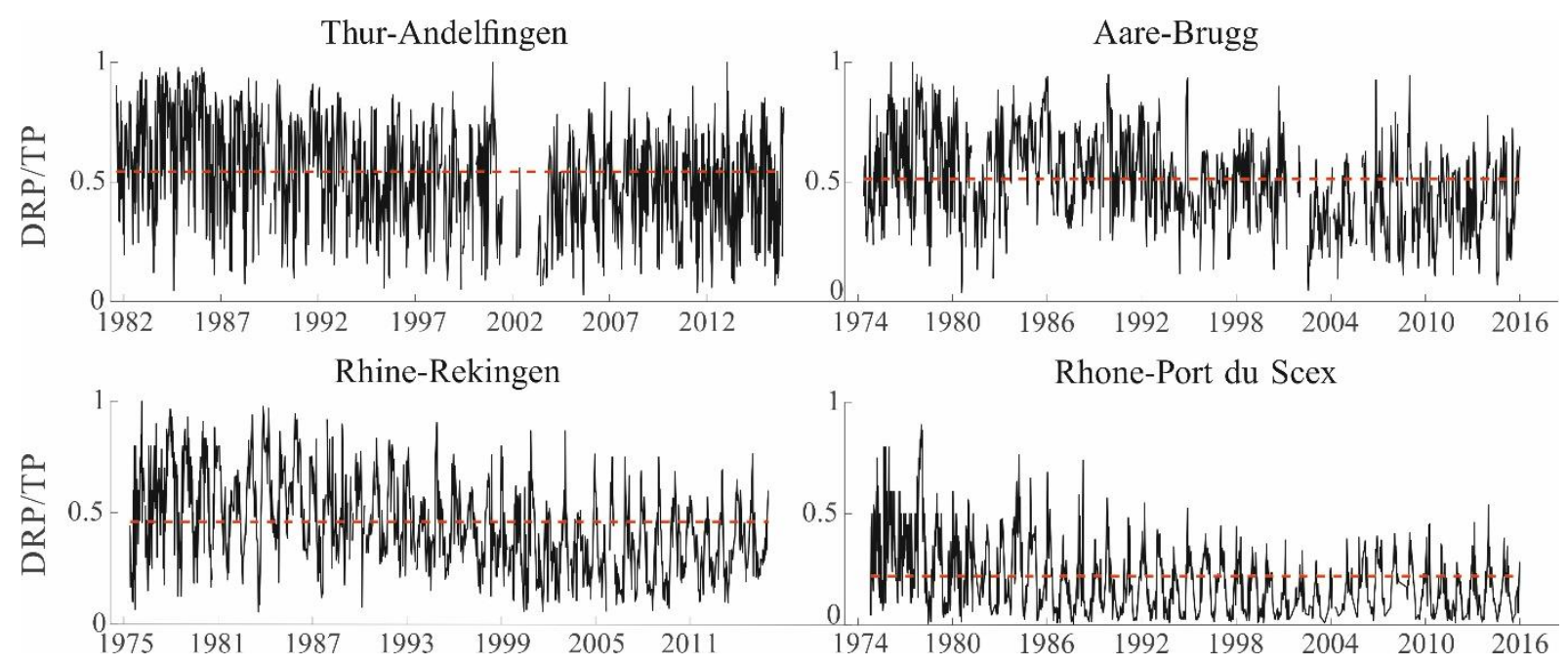

Figure S7. Ratios of DRP/TP in time across four different catchments. The red dashed line represents the average value of the DRP/TP ratio computed on the entire monitoring period. All the selected catchments show significant decrease of DRP/TP ratio in time.

Table S1. Spearman's correlation coefficient between (a) the median concentrations of each solute, (b) the b exponent for low-flows and (c) the b exponent for high-flows across the catchments with some catchment 


\begin{tabular}{|c|c|c|c|c|c|c|c|c|c|c|c|c|}
\hline \multicolumn{13}{|c|}{ (b) b exponent inf } \\
\hline & $\mathrm{Ca}^{2+}$ & $\mathrm{Mg}^{2+}$ & $\mathrm{Na}^{+}$ & $\mathrm{H}_{4} \mathrm{SiO}_{4}$ & $\mathbf{K}^{+}$ & $\mathrm{Cl}^{-}$ & $\mathrm{NO}_{3}$ & TN & DRP & TP & DOC & TOC \\
\hline Catchment area & 0.51 & 0.54 & -0.14 & 0.17 & -0.09 & -0.21 & -0.28 & -0.17 & -0.20 & -0.14 & -0.22 & 0.15 \\
\hline Average altitude & -0.72 & -0.63 & -0.24 & -0.40 & -0.16 & -0.46 & -0.49 & -0.43 & -0.26 & 0.24 & -0.25 & 0.33 \\
\hline $\begin{array}{l}\text { Mean annual } \\
\text { precipitation }\end{array}$ & 0.01 & -0.10 & 0.04 & 0.15 & 0.16 & 0.42 & 0.58 & 0.44 & 0.58 & 0.48 & 0.34 & 0.07 \\
\hline $\begin{array}{l}\text { Mean annual } \\
\text { discharge }\end{array}$ & -0.57 & -0.40 & 0.14 & -0.27 & 0.45 & 0.24 & 0.27 & 0.23 & 0.41 & 0.62 & 0.33 & 0.49 \\
\hline Lake area & 0.55 & 0.58 & 0.08 & 0.18 & -0.04 & -0.08 & -0.40 & -0.25 & -0.28 & -0.25 & -0.28 & -0.11 \\
\hline $\begin{array}{l}\text { \% of Swiss } \\
\text { Plateau area }\end{array}$ & 0.68 & 0.49 & -0.03 & 0.49 & -0.18 & 0.09 & 0.10 & 0.06 & 0.18 & -0.19 & 0.22 & -0.16 \\
\hline$\%$ of Alpine area & -0.56 & -0.32 & 0.17 & -0.32 & 0.25 & -0.08 & -0.05 & -0.02 & -0.11 & 0.34 & 0.02 & 0.38 \\
\hline $\begin{array}{l}\% \text { of intensive } \\
\text { agricultural area }\end{array}$ & 0.76 & 0.48 & -0.05 & 0.51 & -0.19 & 0.14 & 0.13 & 0.07 & 0.18 & -0.28 & 0.05 & -0.28 \\
\hline $\begin{array}{l}\% \text { of extensive } \\
\text { agricultural area }\end{array}$ & -0.75 & -0.48 & 0.08 & -0.52 & 0.44 & 0.12 & 0.10 & 0.13 & 0.24 & 0.44 & 0.45 & 0.45 \\
\hline $\begin{array}{l}\text { Inhabitants } \\
\text { density }\end{array}$ & 0.70 & 0.53 & -0.13 & 0.48 & -0.38 & -0.13 & -0.07 & -0.20 & -0.19 & -0.37 & -0.17 & -0.18 \\
\hline
\end{tabular}

(a) Median solute concentration

\begin{tabular}{|c|c|c|c|c|c|c|c|c|c|c|c|c|}
\hline \multicolumn{13}{|c|}{ (a) Median solute concentration } \\
\hline & $\mathrm{Ca}^{2+}$ & $\mathrm{Mg}^{2+}$ & $\mathrm{Na}^{+}$ & $\mathrm{H}_{4} \mathrm{SiO}_{4}$ & $\mathbf{K}^{+}$ & $\mathrm{Cl}^{-}$ & $\mathrm{NO}_{3}$ & $\mathbf{T N}$ & DRP & $\mathbf{T P}$ & DOC & TOC \\
\hline Catchment area & 0.36 & -0.03 & 0.37 & 0.38 & -0.38 & 0.18 & 0.27 & 0.33 & 0.18 & 0.04 & 0.54 & 0.51 \\
\hline Average altitude & -0.64 & -0.55 & -0.67 & -0.73 & -0.08 & -0.63 & -0.78 & -0.75 & -0.75 & -0.54 & -0.32 & -0.41 \\
\hline $\begin{array}{l}\text { Mean annual } \\
\text { precipitation }\end{array}$ & -0.05 & 0.00 & -0.01 & -0.02 & 0.15 & 0.11 & 0.12 & 0.05 & 0.15 & 0.17 & -0.34 & -0.35 \\
\hline $\begin{array}{l}\text { Mean annual } \\
\text { discharge }\end{array}$ & -0.69 & -0.54 & -0.65 & -0.72 & -0.28 & -0.57 & -0.66 & -0.67 & -0.58 & -0.51 & -0.33 & -0.43 \\
\hline Lake area & 0.45 & -0.13 & 0.09 & 0.19 & -0.24 & 0.02 & 0.09 & 0.12 & -0.02 & -0.19 & 0.42 & 0.30 \\
\hline $\begin{array}{l}\text { \% of Swiss } \\
\text { Plateau area }\end{array}$ & 0.83 & 0.63 & 0.83 & 0.85 & 0.25 & 0.73 & 0.91 & 0.91 & 0.80 & 0.63 & 0.42 & 0.51 \\
\hline$\%$ of Alpine area & -0.75 & -0.44 & -0.70 & -0.77 & 0.03 & -0.63 & -0.83 & -0.83 & -0.74 & -0.57 & -0.22 & -0.35 \\
\hline $\begin{array}{l}\% \text { of intensive } \\
\text { agricultural area }\end{array}$ & 0.88 & 0.38 & 0.78 & 0.87 & -0.15 & 0.68 & 0.85 & 0.87 & 0.78 & 0.58 & 0.54 & 0.63 \\
\hline $\begin{array}{l}\% \text { of extensive } \\
\text { agricultural area }\end{array}$ & -0.81 & -0.35 & -0.58 & -0.68 & -0.18 & -0.52 & -0.63 & -0.64 & -0.52 & -0.41 & -0.49 & -0.52 \\
\hline $\begin{array}{l}\text { Inhabitants } \\
\text { density }\end{array}$ & 0.77 & 0.40 & 0.70 & 0.72 & 0.05 & 0.57 & 0.67 & 0.69 & 0.56 & 0.40 & 0.55 & 0.57 \\
\hline
\end{tabular}

characteristics listed in the first column. The green cells represent the significant correlations, i.e., the correlations characterized by a $\mathrm{p}$ value lower than the significance threshold $\alpha$ fixed at 0.05 . 


\begin{tabular}{|lcccccccccccc|}
\hline & \multicolumn{10}{c|}{ (c) b exponent sup } \\
\hline & $\mathrm{Ca}^{2+}$ & $\mathbf{M g}^{2+}$ & $\mathbf{N a}^{+}$ & $\mathbf{H}_{4} \mathrm{SiO}_{4}$ & $\mathbf{K}^{+}$ & $\mathrm{Cl}^{-}$ & $\mathbf{N O}_{3}$ & $\mathbf{T N}$ & $\mathbf{D R P}$ & $\mathbf{T P}$ & DOC & TOC \\
\hline Catchment area & 0.78 & 0.59 & 0.21 & 0.13 & -0.12 & -0.40 & -0.17 & 0.16 & -0.35 & 0.09 & 0.03 & 0.50 \\
\hline Average altitude & -0.69 & -0.77 & -0.28 & -0.53 & -0.75 & -0.40 & -0.53 & -0.18 & -0.28 & 0.30 & -0.29 & -0.04 \\
\hline $\begin{array}{l}\text { Mean annual } \\
\text { precipitation }\end{array}$ & -0.14 & 0.01 & -0.53 & 0.10 & 0.40 & 0.24 & 0.37 & 0.06 & 0.35 & -0.41 & 0.30 & -0.35 \\
\hline $\begin{array}{l}\text { Mean annual } \\
\text { discharge }\end{array}$ & -0.62 & -0.63 & -0.65 & -0.43 & -0.25 & 0.01 & -0.06 & 0.03 & 0.05 & -0.18 & -0.02 & -0.38 \\
\hline Lake area & 0.67 & 0.56 & 0.49 & 0.01 & -0.15 & -0.28 & -0.38 & 0.03 & -0.53 & -0.19 & -0.05 & 0.28 \\
\hline $\begin{array}{l}\text { \% of Swiss } \\
\text { Plateau area }\end{array}$ & 0.72 & 0.74 & 0.41 & 0.48 & 0.47 & 0.15 & 0.38 & 0.47 & 0.23 & -0.02 & 0.70 & 0.30 \\
\hline \% of Alpine area & -0.59 & -0.62 & -0.21 & -0.35 & -0.46 & -0.11 & -0.31 & 0.04 & -0.13 & 0.22 & -0.22 & -0.02 \\
\hline $\begin{array}{l}\text { \% of intensive } \\
\text { agricultural area }\end{array}$ & 0.79 & 0.75 & 0.27 & 0.47 & 0.42 & 0.00 & 0.24 & 0.36 & 0.13 & -0.09 & 0.59 & 0.29 \\
\hline $\begin{array}{l}\text { \% of extensive } \\
\text { agricultural area }\end{array}$ & -0.76 & -0.76 & -0.45 & -0.53 & -0.20 & 0.19 & 0.09 & 0.21 & 0.24 & -0.02 & 0.02 & -0.53 \\
\hline $\begin{array}{l}\text { Inhabitants } \\
\text { density }\end{array}$ & 0.77 & 0.73 & 0.33 & 0.40 & 0.11 & -0.28 & -0.07 & 0.21 & -0.18 & 0.03 & 0.41 & 0.56 \\
\hline
\end{tabular}

Table S2. Monthly trend analysis: results of Mann- Kendall test on a monthly basis. The significant trends are highlighted with the grey boxes and the sign $+/$ - refers respectively to positive or negative trends, while the darkto-light blue refers to the gradient of intensive agriculture in the basins (Table 1). Tables a) refer to solutes that showed clear increasing or decreasing trend in the long-term trend analysis. Tables b) refer to solutes that showed a non-monotonic trend, while Tables c) include solutes that did not show any clear trend in the longterm.

a)

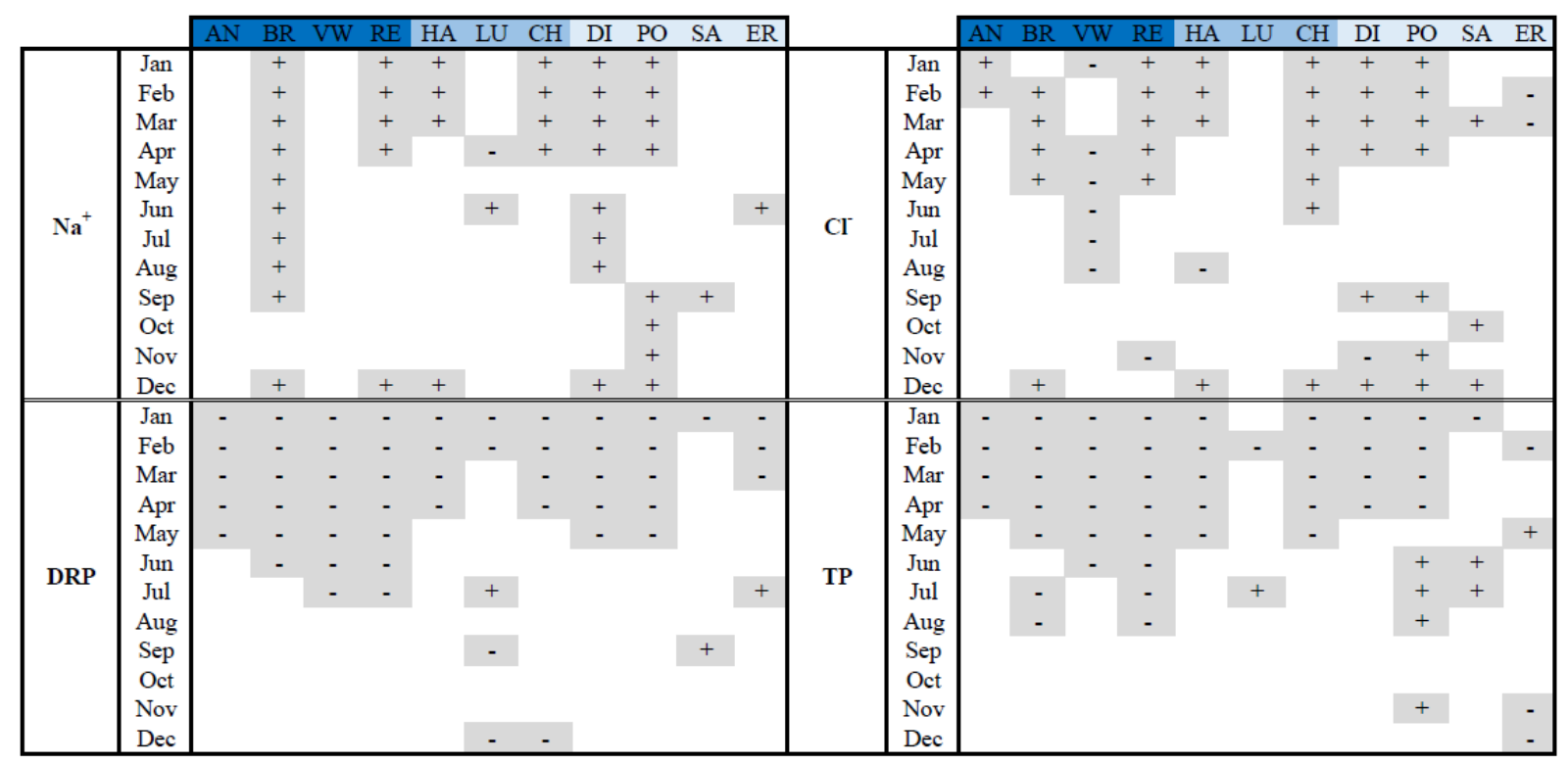




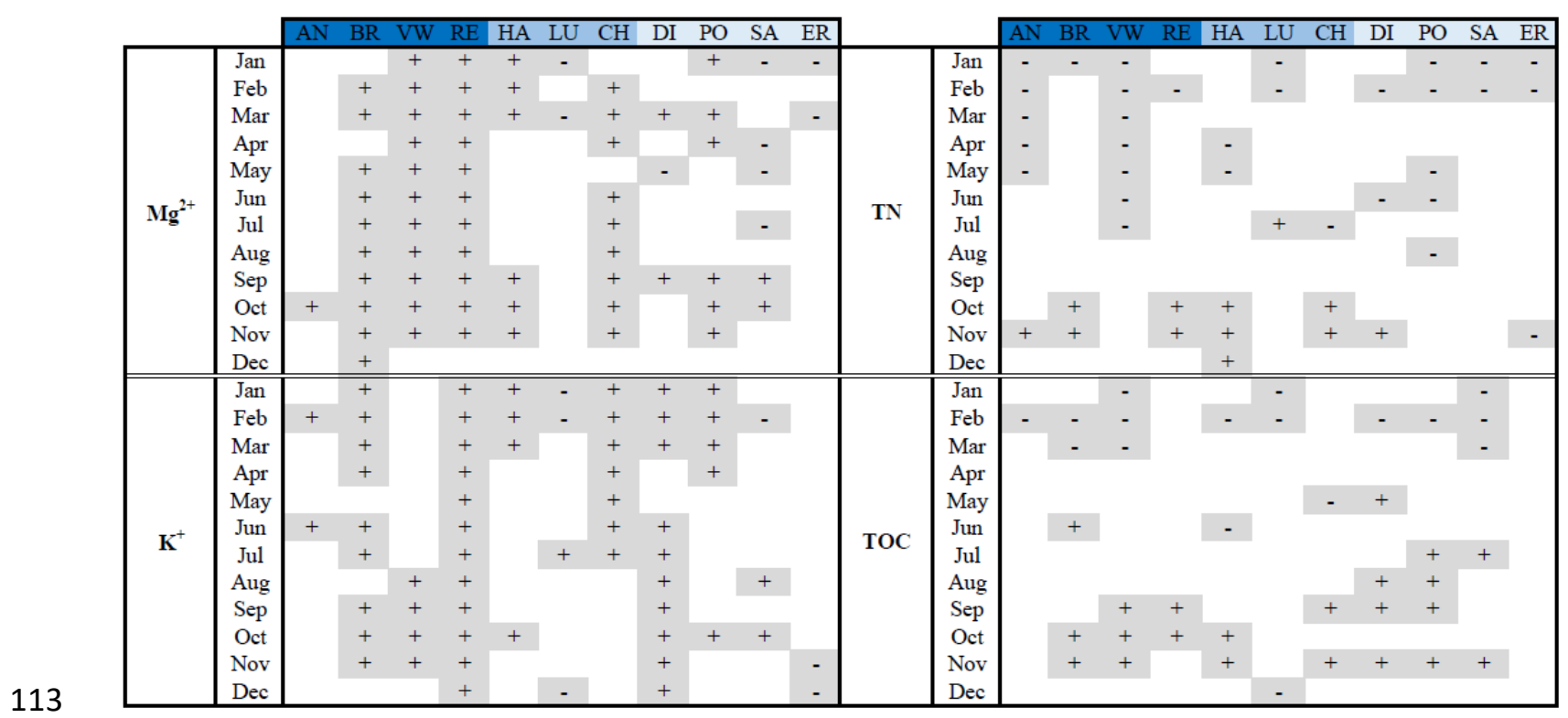

114 c)

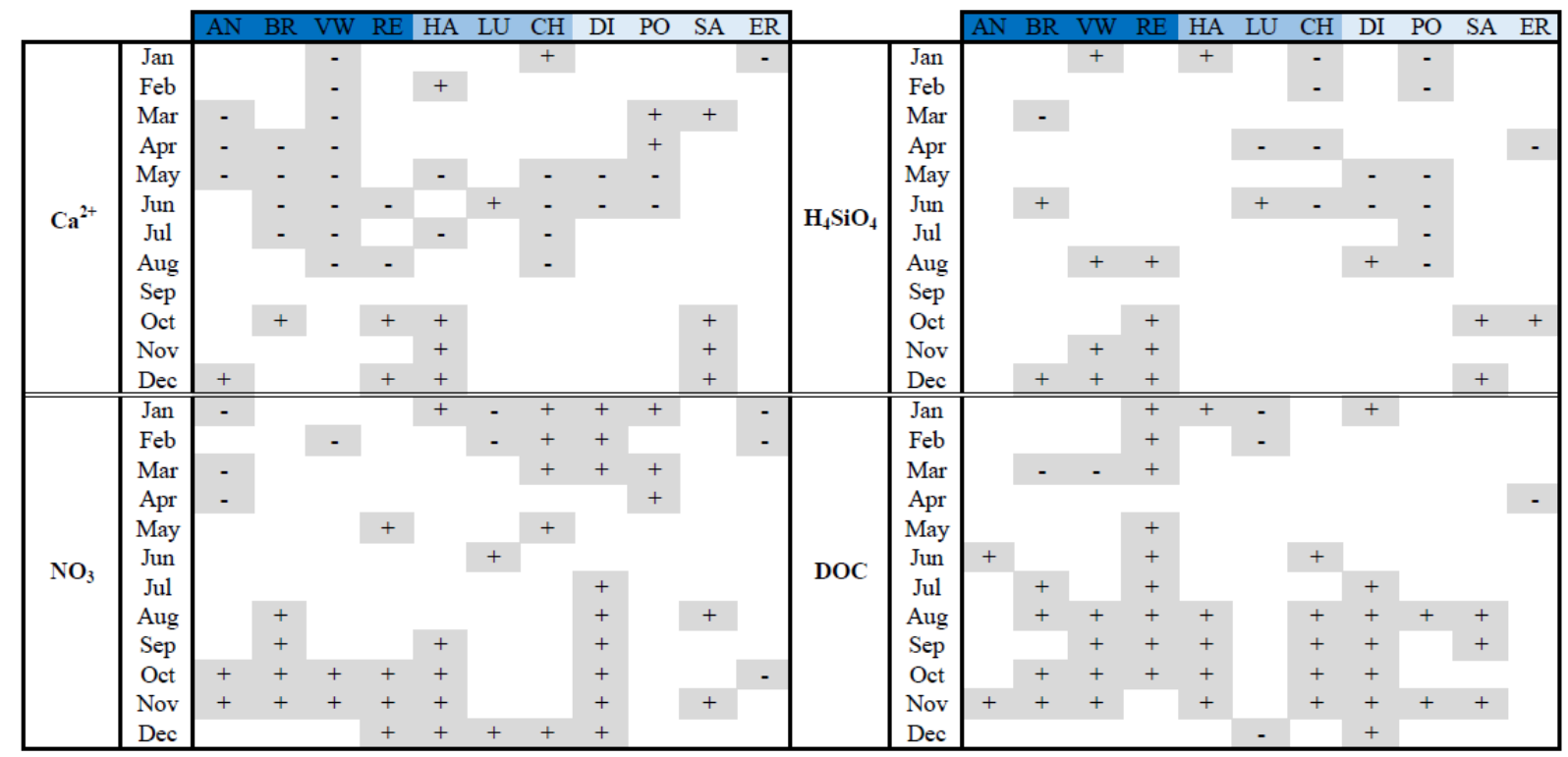

